\title{
Sustaining STEM Initiatives: The Challenge of a Worthy Investment
}

Melissa B. Crawford, ${ }^{\dagger}$ Tyrslai M. Williams, ${ }^{\dagger}$ Zakiya Wilson-Kennedy, ${ }^{\ddagger}$ Linda Hooper-Bui, ${ }^{\$}$ Megan Stone, ${ }^{\dagger}$ and Isiah M. Warner ${ }^{\dagger *}$

${ }^{\dagger}$ Office of Strategic Initiatives, ${ }^{\ddagger}$ College of Science, and \$Department of Environmental Sciences, Louisiana State University, Baton Rouge, LA 70803

$\mathrm{H}^{\mathrm{i}}$ igh attrition rates in science, technology, engineering, and mathematics (STEM) continue to be a challenge in the field, as less than half of those who begin STEM degrees finish successfully (Hayes et al., 2009; Epstein, 2010; Dagley et al., 2016). Attrition rates for underrepresented minorities (URMs) are even higher, resulting in missed opportunities to cultivate future generations of STEM leaders and loss of valuable contributors to the STEM community (National Academy of Sciences, National Academy of Engineering, and Institute of Medicine, 2011; Wilson et al., 2012a,b). The Louisiana State University (LSU) Office of Strategic Initiatives (OSI), led by institutional change agent Isiah Warner, was established in 2001 as an incubator designed to improve the STEM persistence rates of URM (African American, American Indian, Alaskan Native, Latino, and Native Pacific Islander), socially and economically disadvantaged, first-generation, and female students (Crawford et al., 2018).

For nearly two decades, the OSI has functioned as an agent of change at LSU through its implementation of a multifaceted student-training model. The formation of the OSI resulted from the successful recruitment, retention, and graduation of African-American chemistry PhDs after the arrival of Professor Warner in 1992, which gave LSU the distinction of graduating the highest number of African Americans with chemistry doctorates in the nation (Crawford et al., 2018). These achievements attracted the attention of the LSU administration, which provided seed money with a goal to replicate the success of the chemistry department in other departments across the university.

In 2001, OSI began to serve undergraduates through a \$1 million grant awarded to Professor Warner as one of the 20 new Howard Hughes Medical Institute (HHMI) Professors. Professor Warner's HHMI grant was aimed at transforming the academic trajectory of high-potential but underperforming first-year STEM students. Resources grew when, during a meeting with a program officer at the National Science Foundation (NSF), the Meyerhoff Scholars Program at the University of Maryland, Baltimore County, was cited as being a "national model" (Orfield et al., 2007; Carter et al., 2009; Maton et al., 2009, 2012), but professor Warner pointed out that "nothing is a true model until it has been duplicated." This conversation yielded an invitation to submit a proposal to NSF, which resulted in an award and gave rise to the LA-STEM Research Scholars Program. In this program, the OSI has addressed persistence in STEM majors by

1. Building a sense of community through structured group activities;

2. Supporting student learning and development by integrating metacognitive tasks into the professional development and graduate school preparation activities;

3. Offering individualized faculty, staff, and peer mentoring; and

4. Integrating academic-year research as well as domestic and international summer undergraduate research opportunities early into the educational experience.

The LA-STEM program served 249 students (44\% URMs, 53\% women) over a decade with a focus on selecting students with great potential and top students at
Kenneth Gibbs Monitoring Editor Submitted Jun 6, 2018; Accepted Jun 12, 2018 CBE Life Sci Educ September 1, 2018 17:es15 DOI:10.1187/cbe.18-06-0086

*Address correspondence to: Isiah M. Warner (iwarner@lsu.edu).

(c) 2018 M. B. Crawford et al. CBE-Life Sciences Education (๑) 2018 The American Society for Cell Biology. This article is distributed by The American Society for Cell Biology under license from the author(s). It is available to the public under an Attribution-Noncommercial-Share Alike 3.0 Unported Creative Commons License (http://creativecommons.org/licenses/ by-nc-sa/3.0).

"ASCB®" and "The American Society for Cell Biology ${ }^{\circledR}$ " are registered trademarks of The American Society for Cell Biology. 


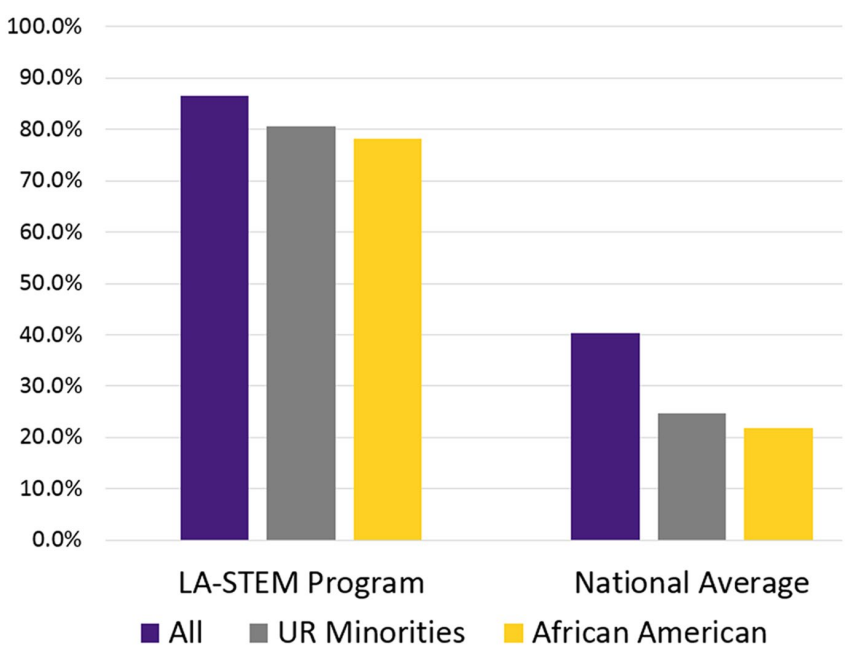

FIGURE 1. Six-year STEM graduation rates.

underresourced secondary schools. To date, $87 \%$ of all LA-STEM participants, $81 \%$ of all students from URM backgrounds, and $78 \%$ of African American students graduated in STEM within 6 years (Figure 1). All of these rates were two to three times the national average, demonstrating that the model is effective for students from all backgrounds. Almost half of LA-STEM graduates completed their degrees with a 3.7 cumulative GPA or higher, and a substantial number of these scholars received national honors such as the Barry M. Goldwater Scholarship (8) and NSF Graduate Research Fellowship (18). In fact, between 2003 and 2017, more than $40 \%$ of the total of each of these awards granted to LSU came to students who were part of LA-STEM. Thus, these efforts, which were initially targeted to address differences in success for students from URM groups, have had an institutional impact (Crawford et al., 2018).

Although the LA-STEM model enhanced diversity and increased persistence within the university, it concluded after the external funding ended. While NSF, our largest funding source, acknowledged OSI's tremendous impact on broadening participation, like most funding agencies, it generally supports new ideas and expects successful initiatives to be sustained by the university beyond the conclusion of the grant. Efforts to institutionalize program elements have been unsuccessful, as prevailing state budget cuts have led to an increased strain on LSU's funding.

We see this as one of the main challenges to broadening participation: we must channel institutional resources for effective programming so that the benefits do not simply dissipate when external funding does. Often universities are hesitant to sustain smaller student-support programs aimed at increasing diversity, particularly those that offer participant support. This reluctance stems from the inability to see a large return on their investment in modest student populations. A lapse in funding and programming is an unfortunate setback for efforts to sustain the momentum needed to truly broaden participation. Oftentimes other departments, faculty, and staff see and applaud the efforts of an office like OSI but are unwilling to allocate their own resources to such efforts or assume a similar role themselves. Universities and funding agencies must consider how effective interventions will be sustained.

It is imperative that, along with establishing interventions and initiatives focused on broadening participation, local change agents develop strategic plans for sustainability from the beginning, giving careful consideration to diversity in the types and levels of institutional supports.

Ideally, a healthy balance between the following key elements would better secure the longevity of programming with demonstrated efficacy for broadening participation, such as LA-STEM:

- Early advocacy by senior administrators

- Buy-in of faculty

- Better exposure and dissemination of best practices

- Secured donor support

In spite of the prevailing obstacles, there is one undeniable outcome that is sustainable, even with the absence of fundingchanged perspectives. Institutional change efforts like those of OSI have redefined success in STEM and what it "looks like." This intangible measure is perhaps the most profound and worth any investment.

\section{ACKNOWLEDGMENTS}

We acknowledge all current and past staff/students of the Office of Strategic Initiatives at Louisiana State University for their valuable contributions to making this office a true change agent at LSU. We also acknowledge grants from the Howard Hughes Medical Institute, the National Science Foundation, Research Corporation, and the Louisiana Board of Regents for support of work done in this office..

\section{REFERENCES}

Carter, F. D., Mandell, M., \& Maton, K. I. (2009). The influence of on-campus, academic year undergraduate research on STEM Ph.D. outcomes: Evidence from the Meyerhoff Scholarship Program. Educational Evaluation and Policy Analysis, 31(4), 441-462.

Crawford, M. B., Wilson-Kennedy, Z. S., Thomas, G. A., Gilman, S. D., \& Warner, I. M. (2018). LA-STEM Research Scholars Program: A model for broadening diversity in STEM education. Technology \& Innovation, 19(3), 577-592.

Dagley, M., Georgiopoulos, M., Reece, A., \& Young, C. (2016). Increasing retention and graduation rates through a STEM learning community. Journal of College Student Retention: Research, Theory \& Practice, 18(2), 167-182.

Epstein, J. (2010). Graduation gaps for science majors. Электрон ный ресурс] Режим доступа: Retrieved August 24, 2018, from www.insidehighered .com/news/2010/02/17/graduation-gaps-science-majors [Цит. по cocm.: 12 июля 2010 2.]

Hayes, R., Whalen, S., \& Cannon, B. (2009). CSRDE STEM retention report, 2008-2009. Norman: Center for Institutional Data Exchange and Analysis, University of Oklahoma.

Maton, K. I., Domingo, M. R. S., Stolle-McAllister, K. E., Zimmerman, J. L., \& Hrabowski, F. A., III. (2009). Enhancing the number of African-Americans who pursue STEM PhDs: Meyerhoff Scholarship Program outcomes, processes, and individual predictors. Journal of Women and Minorities in Science and Engineering, 15(1), 15-37.

Maton, K. I., Pollard, S. A., McDougall Weise, T. V., \& Hrabowski, F. A. (2012). Meyerhoff Scholars Program: A strengths-based, institution-wide approach to increasing diversity in science, technology, engineering, and mathematics. Mount Sinai Journal of Medicine, 79(5), 610-623.

National Academy of Sciences, National Academy of Engineering, and Institute of Medicine. (2011). Expanding underrepresented minority participation: America's science and technology talent at the crossroads. Washington, DC: National Academies Press. 
Orfield, G., Marin, P., Flores, S. M., \& Garces, L. M. (2007). Charting the future of college affirmative action: Legal victories, continuing attacks, and new research. Los Angeles: Civil Rights Project/Proyecto Derechos Civiles.

Wilson, Z. S., Holmes, L., Sylvain, M. R., Batiste, L., Johnson, M., McGuire, S. Y., . Warner, I. M. (2012a). Hierarchical mentoring: A transformative strategy for improving diversity and retention in undergraduate STEM disciplines. Journal of Science Education and Technology, 21(1), 148-156.

Wilson, Z. S., Iyengar, S. S., Pang, S.-S., Warner, I. M., \& Luces, C. A. (2012b) Increasing access for economically disadvantaged students: The NSF/ CSEM \& S-STEM programs at Louisiana State University. Journal of Science Education and Technology, 21(5), 581-587. 